\title{
Factors Explaining the Market Discipline of Sharia Mutual Funds from a Behavioural Finance Perspective: A Theoretical Approach
}

Submitted 20/04/19, 1st revision 10/05/19, 2nd revision 23/06/19, accepted 27/07/19

\author{
Umi Widyastuti ${ }^{1}$, Erie Febrian ${ }^{2}$, Sutisna ${ }^{3}$, Tettet Fitrijanti ${ }^{4}$
}

\begin{abstract}
:
Purpose: This paper aims to develop propositions about the antecedents of market discipline of Sharia mutual funds.

Design/Methodology/Approach: This paper elaborates some scholars, which have applied Theory of Planned Behaviour to predict financial behavior, for developing the propositions. Findings: This paper define market discipline of Sharia mutual funds as withdrawal behaviour that reflects investor sensitivity to excessive risks taken by fund managers from a behavioral perspective, that could be affected by pscyhological and social factors.

Practical Implications: This paper proposes certain variables which can be employed as the determinants of market discipline, including Islamic financial literacy, financial risk tolerance, attitude towards withdrawal, subjective norms, perceived behavioural control and withdrawal intentions.

Originality/Value: This paper fill a lack of studies which discuss market discipline from the perspective of behavioural finance.
\end{abstract}

Keywords: market discipline, attitude towards withdrawal, subjective norm, perceived behavioral control, withdrawal intention, Sharia mutual funds.

JEL code: G21, G23, G32.

Paper type: Theoretical paper.

\footnotetext{
${ }^{1}$ Lecturer, Faculty of Economics, Universitas Negeri Jakarta and Ph.D. candidate in Financial Management, Padjadjaran University, Bandung, Indonesia., e-mail: umiwidyastuti_feunj@unj.ac.id ${ }^{2}$ Lecturer, Faculty of Economics and Business, Padjadjaran University, Bandung, Indonesia. e-mail:erie.febrian@unpad.ac.id

${ }^{3}$ Lecturer, Faculty of Economics and Business, Padjadjaran University, Bandung, Indonesia. e-mail: sutisna_mmunpad@yahoo.com

${ }^{4}$ Lecturer, Faculty of Economics and Business, Padjadjaran University, Bandung, Indonesia. Email:tettet.fitrijanti@unpad.ac.id
} 


\section{Introduction}

Market discipline can generally be used to mitigate creditor risk due to excessive risk taking by banks. The asymmetric information that exists between the agent and the principal, or between lenders and borrowers in banking (Beck, Kunt \& Merrouche, 2013), could create an agency problem (Min, 2015). Furthermore, such information could enhance the possibility of the existence of moral hazard (Stephanou, 2010). When moral hazard occurs, actions which are taken by agents will raise the level of risk for investors and increase default risk. To minimise default risk in banking, market discipline has been added as the third pillar of banking regulation. De Ceuster and Masschelein (2003) state that this is intended to facilitate monitoring by market participants and also encourage banks to disclose information about risk management (Benink \& Wihlborg, 2002). Therefore, Stephanou (2010) defines market discipline as the mechanism through which market participants monitor and discipline excessive risk-taking behaviour by banks.

Most of the literature on market discipline measures the risk sensitivity of market participant using secondary data that reflect risk, return and market position (Gorton \& Santomero, 1990). Market participants, who consist of depositors, shareholders and debt holders, may discipline risky banks, either by demanding higher returns or by withdrawing their deposits (Kunt \& Huizinga, 1999; Stephanou, 2010). Therefore, studies on market discipline have predominantly been conducted by considering the conditions usually employed to examine the effectiveness of market discipline (Lane, 1993).

The first condition that influences market discipline is deposit insurance (Khorassani, 2000; Kunt \& Huizinga, 2004), both implicit (Milhaupt, 1999) or explicit (Gropp, Vesala \& Vulpes, 2004) schemes. The impact of deposit insurance on market discipline is also measured based on its value (Laeven \& Valencia, 2012) and design (Kunt \& Huizinga, 2004). The second condition which has been proven to strengthen or weaken market discipline is capital structure. The measurement of this has focused on leverage (Calomiris \& Powell, 2001; Merton, 1977) subordinated note debt (Sironi, 2003) capital buffers (Lindquist, 2003; Nier \& Baumann, 2006) uninsured deposits (Baer \& Brewer, 1986) and reverse convertible debt (Flannery, 2005). The third condition which is considered to affect market discipline is information disclosure (Benink \& Wihlborg, 2002; Febrian \& Herwany, 2011; Goldstein \& Sapra, 2014; Hosono, Iwaki \& Tsuru, 2005; Lane, 1993; Nier \& Baumann, 2006; Stephanou, 2010). The information which is provided in financial reports could be used to predict bank risk. Information disclosure is able to strengthen market discipline. These studies emphasise the fundamental factors in banking that reflect default risk. However, macroeconomic factors also contribute to systemic risk in banking (Levy-Yeyati, Peria \& Schmukler, 2004; Levy-Yeyati, Martinez Peria \& Schmukler, 2010). 
Moreover, based on the previous studies, most market discipline models have been developed in banking, although market discipline is not only required in the banking industry. Bettis and Donaldson (1990) state that market discipline is needed by almost all organisations to overcome efficiency problems, including those in the financial services industry, such as non-bank financial institutions (Hess \& Feng, 2007). Previous research has used the case of mutual funds (Dangl, Wu \& Zechner, 2006), insurance (Eling, 2012; Eling \& Kiesenbauer, 2012) and even other nonbanking investments through markets that are yet to be well regulated (Soma, Primiana, Wiryono \& Febrian, 2016). Nevertheless, there is a lack of studies on Sharia mutual funds, so this study will propose a theoretical paper about the determinants of market discipline amongst Sharia mutual funds investors.

According to Kunt and Huizinga (1999) and Stephanou (2010), market discipline could be explored from the perspective of the withdrawal of investors' funds, so this study defines market discipline as the withdrawal behaviour of investors in Sharia mutual funds. This construct reflects investor sensitivity to excessive risks taken by fund managers (Levy-Yeyati et al., 2004; Min, 2015). Dangl et al. (2006) state that investors in mutual funds could discipline fund managers by withdrawing their money whenever they feel dissatisfied with the investment management services provided. With reference to Abduh (2014), withdrawal behaviour in Islamic banking considers the issue of non-sharia compliance. Therefore, this research will also consider the withdrawal of Sharia mutual funds due to non-sharia compliance.

Behavioural finance has emerged as an alternative approach to exploring investor behavior further (Ozmete \& Hira, 2011) including explanation of withdrawal behaviour. Behavioural finance involves the role of psychological and social factors which influence investors' decision-making (Kourtidis, Šević \& Chatzoglou, 2011). To describe the factors which underpin decisions to withdraw Sharia mutual funds, this study reviews market discipline from a financial behaviour perspective. In measuring market discipline as withdrawal behaviour, reference is made to researchers who have predicted financial behaviour and described individuals' perception of the factors determining such behaviour. Ajzen (1991) states that explaining human behaviour is not easy, because there are so many aspects involved, ranging from psychological processes to the background of the social conditions which influence the behaviour. Ajzen (1991) found that attitudes towards behaviour, subjective norms and perceived behavioural control influence the behavioural intentions and subsequently predict them.

Previous research has employed several variables to determine behavioural intentions and financial behaviour, including past behaviour (East, 1993), risk tolerance (Croy, Gerrans \& Speelman, 2010), financial risk tolerance (Magendans, Gutteling \& Zebel, 2017), risk propensity (Alleyne \& Broome, 2011), risk preference (Mahastanti \& Hariady, 2014), planning importance and planning preparedness (Croy et al., 2010), financial literacy (Kennedy, 2013; Sivaramakrishnan, Srivastava \& Rastogi, 2017), financial knowledge (Xiao, Tang, 
Serido \& Shim, 2011), subjective financial knowledge, perceived saving barriers, promotion focus, prevention focus, and perceived financial self-efficacy (Magendans et al., 2017) and satisfaction (Xiao \& Wu, 2006).

To fill the literature gap, this study is organised to develop a proposition that explains market discipline in Islamic financial services from the investor behaviour perspective. From the behavioural point of view, the study is concerned with understanding better the correlation between market discipline and certain behavioural variables, namely Islamic financial literacy, financial risk tolerance, attitudes towards withdrawal, subjective norms, perceived behavioural control and withdrawal intentions. Consequently, the study develops a theoretical paper about the determinants of market discipline from the perspective of financial behaviour, in order to capture withdrawal behaviour amongst Sharia mutual funds investors.

\section{Literature Review}

The concept of market discipline has been widely discussed in banking, but not been clearly defined (Flannery, 2001). It is generally understood as a situation in which agents face costs that are positively related to risks that banks must take, and to react to these costs (Berger, 1991). Therefore, the basic issue in market discipline is to examine whether the risk (as measured by various financial ratios) is significantly related to the movement of equity and bond prices. If the two are related, then it could be said that market discipline exists (Gorton \& Santomero, 1990).

Market discipline in banking is generally observed from the reaction of shareholders, creditors and depositors (De Ceuster \& Masschelein, 2003; Martinez Peria \& Schmukler, 2001). According to Levy-Yeyati et al. (2004), depositors' reactions to risk can be seen through two approaches: the quantitative and the price approach. The quantitative approach observes depositors' risk sensitivity through the withdrawal behaviour of their deposits, while the price approach considers the presence of market discipline through changes in equity price or debt yields.

Min (2015) explains that market discipline exists to reduce risk through two main effects. First, investors react toward banks' exessive risk taking by withdrawing their funds and/or demanding higher returns on their investments. Second, this market reaction will help regulators to identify risky banks and use price changes as a signal of liquidity risk. Regulators can take certain actions to prevent systemic risk. Depositors and other investors may discipline risky banks by either demanding higher deposit interest rates or withdrawing their savings (Bertay, Kunt \& Huizinga, 2013; Kunt \& Huizinga, 1999; Stephanou, 2010). Eling (2012) states that market discipline could be categorised as either direct or indirect. Depositors and investors directly influence bank management, who take risky decisions to control banks' default risk. Therefore, market discipline could be distinguished in two ways: the ability of investors to monitor changing conditions in banks, and the ability to influence the decisions taken by the banks (Bliss \& Flannery, 2002; Flannery, 2001). 
Previous research has considered market discipline measured by deposit withdrawals to reflect market participants' risk sensitivity (Febrian \& Herwany, 2011; Khorassani, 2000). However, such measurement based on deposit withdrawal or growth has not been able to explain the motivational factors considered in this behaviour. Therefore, this study defines market discipline as withdrawal behaviour from the perspective of behavioural finance, which reflects investors' risk sensitivity in punishing fund managers as a consequence of the excessive risk they have taken.

One of the theories that can be used to predict and understand the factors that determine behaviour is the Theory of Planned Behavior (TPB) (Ajzen, 1991). Ozmete and Hira (2011) state that the reasons for using TPB are that it can determine one's opinion in translating financial behaviour and in considering the pre-conditions (opportunities, resources, skills) required for displaying certain behaviour. In addition, the robustness of TPB has been empirically proven to be able to predict various human behaviours (Croy et al., 2010).

The focus of TPB is on the factor of the intention to display certain behaviour, which is reflected in how hard an effort people make to do this. Intention captures the motivational factors, which are determined by variables including attitude toward behaviour, subjective norms, and perceived behavioural control. In fact, behaviour is also determined by a non-motivational factor called perceived behavioural control, which is defined as the availability of resources and opportunities, such as time, money and skills. Furthermore, individuals' intention and perceived behavioural control interact in influencing their behaviour (Ajzen, 1991).

TPB, which can predict financial behaviour or financial decisions, as well as determine intention, has been widely applied in previous research; for example to determine the intention to buy mutual funds (Schmidt, 2010), to invest (Ali, Zani \& Kasim, 2014; Sondary \& Sudarsono, 2015), to save (Widyastuti, Suhud \& Sumiati, 2016), and to use e-tax service systems (Sondakh, 2017). Several studies as an extension of TPB have been conducted to predict behaviour, such as participation in the stock market (Sivaramakrishnan et al., 2017), withdrawal behaviour in Sharia banking (Abduh, Duasa \& Omar, 2011), investment behaviour (Xiao et al., 2011), financing decisions in family firms (Koropp, Kellermanns, Grichnik \& Stanley, 2014) and use of risky credit (Xiao et al., 2011). However, to the best of our knowledge, no studies have measured market discipline (as withdrawal behaviour) with regard to Sharia mutual funds. Due to the limitation of literature on market discipline in accordance with the research purposes, this study refers to the previous research about intention and financial behavior or decisions. Applying the TPB, withdrawal behavior will be observed using this theory.

According to Ajzen (1991), the main variables in TPB (attitude towards behaviour, subjective norms, and perceived behavioural control) may be broken down, rearranged, and even extended to prove and explain various behaviours. The first main variable of TPB, attitude toward behaviour, is described as an individual's 
evaluation of the outcomes of certain behaviour (Ajzen, 2002). According to Sivaramakrishnan et al. (2017), attitude towards behaviour can be broken down into performance perceptions, the hassle factor, risk aversion and perceptions of regulators. In addition, attitude is sometimes defined as people's attitude towards objects, as reflected in several specific concepts including attitude toward risk tolerance and planning horizon, and credit attitude (Rutherford \& DeVaney, 2009).

Moreover, Magendans et al. (2017) operationalise attitude into the concept of financial risk tolerance. The second main variable of TPB, subjective norms, have been conceptualised in several studies as social influences (Ali et al., 2014), peer and family influence (Jamal, Ramlan, Karim \& Osman, 2015), perceptions of family norms (Koropp et al., 2014), parental and friend norms (Xiao et al., 2011) and subjective saving norms (Magendans et al., 2017). The construct of subjective norms assesses the social pressures of individuals to display certain behaviour or not (Ajzen, 1985). The third main variable of TPB, perceived behavioural control (PBC), is also operationalised in many different constructs. PBC describes the availability of resources and opportunities that support individuals in manifesting certain behaviour (Ajzen, 1991). Sivaramakrishnan et al. (2017) employed various constructs to explain PBC, including objective and subjective financial literacy, financial well-being, and financial advisory support. Other studies have defined PBC as self-efficacy (Sondary \& Sudarsono, 2015), perceived financial self-efficacy (Magendans et al., 2017) and financial self-efficacy (Xiao et al., 2011). PBC could be interpreted as a barrier to exerting particular behaviour, hence some studies have used financial controllability (Xiao et al., 2011) and perceived barriers to saving (Magendans et al., 2017) in measuring PBC.

Previous studies have employed different variables to determine financial behaviour as an extension of the TPB model. These include past behaviour (East, 1993), risk tolerance (Croy et al., 2010) or financial risk tolerance (Magendans et al., 2017), risk propensity (Alleyne \& Broome, 2011) or risk preference (Mahastanti \& Hariady, 2014), the importance of planning and planning preparedness (Croy et al., 2010), financial literacy (Kennedy, 2013; Sivaramakrishnan et al., 2017) or financial knowledge (Xiao et al., 2011), perceived saving constraints and regulations (Magendans et al., 2017) and satisfaction (Xiao \& Wu, 2006). Therefore, the purpose of this study is to develop a theoretical paper that explains the antecedent of market discipline as an extended model of the theory of planned behaviour by adding two variables, namely financial risk tolerance and financial literacy.

\section{Propositions}

This study conceptualises market discipline as the withdrawal behaviour of Sharia mutual funds investors. Because of the limited literature on market discipline relating to the research purposes, the study refers to previous research on intention and financial behaviour. The following section describes the relationship between each variable in explaining market discipline. 


\subsection{The Impact of Islamic Financial Literacy on the Intention to Withdraw Funds}

Financial literacy is one kind of human capital that is needed when someone makes a financial decision. Huston (2010) defines it as a measure of the degree to which one understands key financial concepts and possesses the ability and confidence to manage personal finances through appropriate short-term decision-making and sound, long-range financial planning, while remaining mindful of life events and changing economic conditions. Sivaramakrishnan et al. (2017) found that subjective and objective financial literacy has a direct impact on the intention to participate in the stock market. As the subject of this study is the behaviour related to the withdrawal of Sharia mutual funds within the context of non-sharia compliance, financial literacy is conceptualised as Islamic financial literacy, adapted from Hidajat and Hamdani (2017) and Antara, Musa and Hassan (2016).

Proposition 1: Islamic financial literacy has a positive impact on the intention to withdraw the investments of Sharia mutual funds.

\subsection{The Impact of Financial Risk Tolerance on the Intention to Withdraw Funds}

Factors which have been proven to influence intention are risk propensity (Alleyne $\&$ Broome, 2011) or risk preferences (Mahastanti \& Hariady, 2014). Risk propensity has a positive influence on the intention to invest in shares or to start a new business (Alleyne \& Broome, 2011). Some researchers have used different terms in measuring the risk preference of investors, including risk aversion (Bucciol, Miniaci \& Pastorello, 2017), risk propensity (Alleyne \& Broome, 2011), risk tolerance (Chatterjee, Fan, Jacobs \& Haas, 2017) and financial risk tolerance (Cooper, Kingyens \& Paradi, 2014; Kannadhasan, 2015). This study uses the term financial risk tolerance to explain the willingness of potential investors to bear losses from their investments (Grable \& Lytton, 1999). The financial risk tolerance that describes an investor's risk profile is one of the psychological factors developed to explain the intention to withdraw funds. This study proposes that:

Proposition 2: Financial risk tolerance is predicted to have a negative influence on the intention to withdraw investments of Sharia mutual funds.

\subsection{The Impact of Attitude towards Withdrawal on the Intention to Withdraw Funds}

Previous studies have proven that one's attitude toward behaviour has a significant direct effect on intention (Ali et al., 2014; Alleyne \& Broome, 2011; East, 1993; Kennedy, 2013; Sondakh, 2017). Abduh et al. (2011) explain that the attitude towards withdrawal affects the intention to withdraw funds from saving deposits in Islamic banks. Using the concept of the intention to invest, East (1993), Alleyne and 
Broome (2011), Ali et al. (2014) and Sondary and Sudarsono (2015) found that attitude towards behaviour has a positive impact on the intention to invest. In other words, if investors have a favourable attitude towards investment behaviour, they will tend to have a high intention to invest. With reference to previous work, this study posits that:

Proposition 3: Attitude toward withdrawal is predicted to have positive impact on the intention to withdraw the investments of Sharia mutual funds.

\subsection{The Impact of Subjective Norms on the Intention to Withdraw Funds}

Some studies have shown that all the main variables in TPB have an impact on the intention to invest (Alleyne \& Broome, 2011; East, 1993), including subjective norms. These norms have been broken down into several sources of social influence, including friends' and parental norms (East, 1993; Xiao et al., 2011), family and peers (Jamal et al., 2015) and significant others (Alleyne \& Broome, 2011). Abduh et al. (2011) also found that subjective norms influenced the intention to withdraw both directly and indirectly. It can be interpreted that social influence affects the intention to withdraw savings from Islamic banks. This means that some people and significant others play an important role in influencing depositors' intention to withdraw when Islamic banks offer products and services which violate sharia principles. This study considers the social influence of significant others and friends in measuring subjective norms. Therefore, it is proposed that:

Proposition 4: There is a positive impact of subjective norms on the intention to withdraw the investments of Sharia mutual funds.

\subsection{The Impact of Perceived Behavioural Control on the Intention to Withdraw Funds}

Perceived behavioural control has been empirically proven to influence the intention to invest (Alleyne \& Broome, 2011; East, 1993; Mahastanti \& Hariady, 2014; Schmidt, 2010). Alleyne and Broome (2011) and East (1993) describe perceived behavioural control as how easy or difficult someone believes it is to exhibit certain behavior, with consideration of the knowledge, opportunities and financial resources that people have. The measurement of perceived behavioural control considers two dimensions, namely self-efficacy (Sondary \& Sudarsono, 2015; Xiao et al., 2011) and controllability (Xiao et al., 2011). This study proposes that:

Proposition 5: There is a positive impact of perceived behavioural control on the intention to withdraw the investments of Sharia mutual funds.

\subsection{The Impact of Islamic Financial Literacy on Market Discipline}


Individuals and households need financial literacy to be able to adapt to the current financial system (Henager, 2012). They need to understand certain concepts in financial management and make the right financial decisions (Hassan Al-Tamimi \& Anood Bin Kalli, 2009; Shahrabani, 2012), including market discipline. In this study, financial literacy is predicted to have a positive influence on decisions to withdraw investments from Sharia mutual funds. Soma et al. (2016) and Widdowson and Hailwood (2007) describe the direct effect of financial literacy on market discipline. Those with better financial literacy are expected to be able to exert market discipline on financial service providers. People should consider the risk borne by financial institutions and their financial products and be aware of the tradeoffs between risk and the rate of return (Widdowson \& Hailwood, 2007). This study defines market discipline as the redemption of Sharia mutual funds investments. Furthermore, it develops the proposition that:

Proposition 6: There is a positive influence of Islamic financial literacy on the market discipline of Sharia mutual funds.

\subsection{The Impact of Financial Risk Tolerance on Market Discipline}

Financial risk tolerance is a variable included in the proposed model because it is assumed to be a fundamental issue underlying a number of financial decisions (Grable \& Lytton, 1999). According to Jacobs-Lawson and Hersheym (2005), financial risk tolerance shows a significant effect on saving behaviour for retirement, while Aren and Aydemir (2015) state that risk aversion has a negative influence on risky investment behaviour. The concept of risk tolerance has the opposite meaning to risk aversion. Aren and Zengin (2016) found that perceptions of risk proved to be effective in influencing people's preferences for investment. The level of risk aversion or risk tolerance will determine the investments chosen, whether in stocks, the money market, savings or portfolios. Based such previous research, this study develops the proposition that:

Proposition 7: There is a positive impact of financial risk tolerance on the market discipline of Sharia mutual funds.

\subsection{The Impact of Attitude towards Withdrawal of Funds on Market Discipline}

According to Kaveri and Bindu (2017), attitude has a significant influence on investment decisions in mutual funds, indicating positive assessment of portfolio diversification, investment maturity and investment risk. This claim is supported by Jangid and Sachin (2017), who found that attitude has a positive influence on mutual fund investment decisions in Malaysia. Based on the references above, this study proposes that: 
Proposition 8: Attitudes towards withdrawal of funds affect the market discipline of Sharia mutual funds.

\subsection{The Impact of Subjective Norms on Market Discipline}

Several studies have broken down the concept of subjective norms into social influence, or more specifically family influence, peer influence or family norms, for example. Based on some studies, it has been established that family and peers affect saving behaviour (Jamal et al., 2015) and that parents have a positive influence on the future orientation of their children. Xiao et al. (2011) proved that parents significantly influence their children's financial behaviour and well-being, and provide direct evidence concerning the acquisition of credit cards. This study addresses the following proposition:

Proposition 9: There is a positive impact of subjective norms on the market discipline of Sharia mutual funds.

\subsection{The Impact of Perceived Behavioural Control on Market Discipline}

Fishbein and Ajzen (1975) state that perceived behavioural control explains the individual's self-efficacy perceived in exhibiting certain behaviour. Hrubes, Ajzen and Daigle (2001) claim that perceived behavioural control directly influences behaviour. When people feel more at ease doing something, the greater the likelihood that particular behaviour can be realised. Due to the lack of attention in the literature concerning market discipline from the perspective of behavioural finance, this study uses investment behaviour and other financial behaviour to explain the relationship between the two variables. Xiao and $\mathrm{Wu}$ (2006) found that perceived control has a positive effect on behaviour to retain as a credit counseling client. Magendans et al. (2017) show that financial self-efficacy has a positive influence on saving behaviour. Using self-efficacy and controllability to measure perceived behavioural control, this study develops the proposition that:

Proposition 10: There is a positive impact of perceived behavioural control on the market discipline of Sharia mutual funds.

\subsection{The Impact of the Intention to Withdraw Funds on Market Discipline}

This study considers the impact of the intention to withdraw funds on the market discipline of Sharia mutual funds investors. It refers to studies which have applied TPB to measure the direct effect of intention on behaviour. East (1993) shows that an interest in investing has a positive influence on investment decisions. This study also refers to Abduh et al. (2011), who found an impact of intention on withdrawal behaviour. Therefore, the proposition developed in this study is that: 
Proposition 11: There is a positive impact of the intention to withdraw funds on the market discipline of Sharia mutual funds.

Based on the literature discussed above, the variables proposed in this study which determine market discipline both directly and indirectly include Islamic financial literacy, financial risk tolerance, attitude toward withdrawals, subjective norms, perceived behavioural control, and intention to withdraw. Figure (1) shows the relationship between each construct proposed.

Figure 1: Relationship between each construct

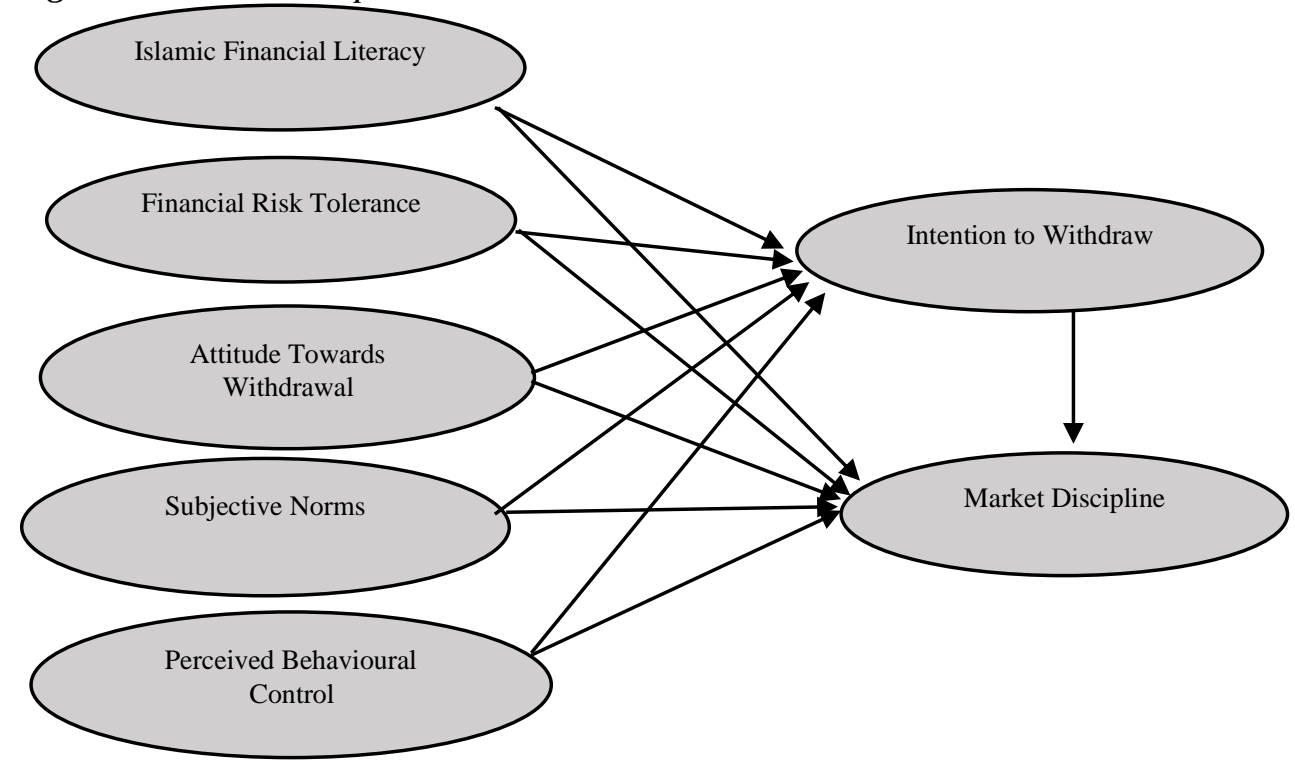

\section{Conclusion}

Market discipline is not only required in the banking industry, but also in Sharia mutual funds. This study aims to develop a theoretical paper to predict market discipline, which is defined as the withdrawal behaviour of Sharia mutual funds investors. Behavioural finance is an emerging field of study and generally explores the role of psychological and social factors in investors' decision-making. However, based on previous research, it has been found that there is a gap in the literature which discusses the antecedents of the market discipline of mutual fund investors from the perspective of behavioural financial. This study offers propositions to explain and to fill this research gap.

\section{References:}

Abduh, M. 2014. Withdrawal Behavior of Malaysian Islamic Bank Customers: Empirical Evidence from Three Major Issues. Journal of Islamic Banking \& Finance, 31(4), 43-54. 
Abduh, M., Duasa, J. \& Omar, M.A. 2011. Factors influence depositors' withdrawal behavior in Islamic banks: A theory of reasoned action. World Academy of Science, Engineering and Technology, 60, 2074-2079.

Ajzen, I. 1985. From intentions to actions: A theory of planned behavior Action control (pp. 11-39). Berlin, Heidelberg: Springer.

Ajzen, I. 1991. The theory of planned behavior. Organizational behavior and human decision processes, 50(2), 179-211.

Ajzen, I. 2002. Constructing a TPB questionnaire: Conceptual and methodological considerations. Retrieved from http://people.umass.edu/ aizen/pdf/tpb.measurement.pdf

Ali, S., Zani, R.M. \& Kasim, K. 2014. Factors Influencing Investors' Behavior in Islamic Unit Trust: An Application of Theory of Planned Behavior. Journal of Islamic Economics, Banking and Finance, 10(2), 183-201.

Alleyne, P. \& Broome, T. 2011. Using the theory of planned behaviour and risk propensity to measure investment intentions among future investors. Journal of Eastern Caribbean Studies, 36(1), 1-20.

Antara, P.M., Musa, R. \& Hassan, F. 2016. Bridging Islamic financial literacy and halal literacy: the way forward in halal ecosystem. Procedia Economics and Finance, 37, 196-202.

Aren, S. \& Aydemir, S.D. 2015. The moderation of financial literacy on the relationship between individual factors and risky investment intention. International Business Research, 8(6), 17-28.

Aren, S. \& Zengin, A.N. 2016. Influence of Financial Literacy and Risk Perception on Choice of Investment. Procedia-Social and Behavioral Sciences, 235, 656-663.

Baer, H. \& Brewer, E. 1986. Uninsured deposits as a source of market discipline: Some new evidence. Economic Perspectives, 10(5), 23-31.

Beck, T., Kunt, A.D. \& Merrouche, O. 2013. Islamic vs. conventional banking: Business model, efficiency and stability. Journal of Banking \& Finance, 37(2), 433-447.

Benink, H. \& Wihlborg, C. 2002. The new Basel capital accord: making it effective with stronger market discipline. European Financial Management, 8(1), 103-115.

Berger, A.N. 1991. Market discipline in banking. Paper presented at the Federal Reserve Bank of Chicago.

Bertay, A.C., Kunt, A.D. \& Huizinga, H. 2013. Do we need big banks? Evidence on performance, strategy and market discipline. Journal of Financial Intermediation, 22(4), 532-558.

Bettis, R.A. \& Donaldson, L. 1990. Market Discipline and the Discipline of Management. The Academy of Management Review, 15(3), 367-368.

Bliss, R.R. \& Flannery, M.J. 2002. Market discipline in the governance of US bank holding companies: Monitoring vs. influencing. Review of Finance, 6(3), 361-396.

Bucciol, A., Miniaci, R. \& Pastorello, S. 2017. Return expectations and risk aversion heterogeneity in household portfolios. Journal of Empirical Finance, 40, 201-219.

Calomiris, C.W. \& Powell, A. 2001. Can emerging market bank regulators establish credible discipline? the case of Argentina 1992-99 Prudential Supervision: What Works and What Doesn't (pp. 147-196). Chicago, Illinois: University of Chicago Press.

Chatterjee, S., Fan, L., Jacobs, B. \& Haas, R. 2017. Risk Tolerance and Goals-Based Savings Behavior of Households: The Role of Financial Literacy. Retrieved from https://ssrn.com/abstract=2918014 
Cooper, W.W., Kingyens, A.T. \& Paradi, J.C. 2014. Two-stage financial risk tolerance assessment using data envelopment analysis. European Journal of Operational Research, 233(1), 273-280.

Croy, G., Gerrans, P. \& Speelman, C. 2010. The role and relevance of domain knowledge, perceptions of planning importance, and risk tolerance in predicting savings intentions. Journal of Economic Psychology, 31(6), 860-871.

Dangl, T., Wu, Y. \& Zechner, J. 2006. Market discipline and internal governance in the mutual fund industry. The Review of Financial Studies, 21(5), 2307-2343.

De Ceuster, M.J.K. \& Masschelein, N. 2003. Regulating banks through market discipline: a survey of the issues. Journal of Economic Surveys, 17(5), 749-766.

East, R. 1993. Investment decisions and the theory of planned behaviour. Journal of Economic Psychology, 14(2), 337-375.

Eling, M. 2012. What do we know about market discipline in insurance? Risk Management and Insurance Review, 15(2), 185-223.

Eling, M. \& Kiesenbauer, D. 2012. Does surplus participation reflect market discipline? An analysis of the German life insurance market. Journal of Financial Services Research, 42(3), 159-185.

Febrian, E. \& Herwany, A. 2011. Depositor sensitivity to risk of islamic and conventional banks: evidence from Indonesia. The International Journal of Business and Finance Research, 5(3), 29-44.

Fishbein, M. \& Ajzen, I. 1975. Belief, attitude, intention, and behaviour: An introduction to theory and research. Reading MA: Addision-Wesley, 369-382.

Flannery, M.J. 2001. The faces of "market discipline". Journal of Financial Services Research, 20(2), 107-119.

Flannery, M.J. 2005. No pain, no gain? Effecting market discipline via reverse convertible debentures Capital adequacy beyond Basel: Banking, securities, and insurance (pp. 171-196). New York: Oxford University Press.

Goldstein, I. \& Sapra, H. 2014. Should banks' stress test results be disclosed? An analysis of the costs and benefits. Foundations and Trends in Finance, 8(1), 1-54.

Gorton, G. \& Santomero, A.M. 1990. Market discipline and bank subordinated debt: Note. Journal of Money, Credit and Banking, 22(1), 119-128.

Grable, J.E. \& Lytton, R.H. 1999. Financial risk tolerance revisited: the development of a risk assessment instrument. Financial services review, 8, 163-181.

Gropp, R., Vesala, J.M. \& Vulpes, G. 2004. Market indicators, bank fragility and indirect market discipline. FRBNY Economic Policy Review.

Hassan Al-Tamimi, H.A. \& Anood Bin Kalli, A. 2009. Financial literacy and investment decisions of UAE investors. The Journal of Risk Finance, 10(5), 500-516.

Henager, R. 2012. A Practical Tool to Measure Financial Literacy. Consumer Interests Annual, 58.

Hess, K. \& Feng, G. 2007. Is there market discipline for New Zealand non-bank financial institutions? Journal of International Financial Markets, Institutions and Money, 17(4), 326-340.

Hidajat, T. \& Hamdani, M. 2017. Measuring Islamic Financial Literacy. Advanced Science Letters, 23(8), 7173-7176.

Hosono, K., Iwaki, H. \& Tsuru, K. 2005. Banking crises, deposit insurance, and market discipline: lessons from the Asian crises RIETI Discussion Paper Series, 05-E-029.

Hrubes, D., Ajzen, I. \& Daigle, J. 2001. Predicting hunting intentions and behavior: An application of the theory of planned behavior. Leisure Sciences, 23(3), 165-178.

Huston, S.J. 2010. Measuring financial literacy. Journal of Consumer Affairs, 44(2), 296. 
Jacobs-Lawson, J.M. \& Hersheym, D.A. 2005. Influence of future time perspective, financial knowledge, and financial risk tolerance on retirement saving behavior. Financial services review, 14, 331-344.

Jamal, A.A.A., Ramlan, W.K., Karim, M.A. \& Osman, Z. 2015. The effects of social influence and financial literacy on savings behavior: A study on students of higher learning institutions in Kota Kinabalu, Sabah. International Journal of Business and Social Science, 6(11), 110-119.

Jangid, M.V. \& Sachin, M. 2017. Investors' Opinion Regarding the Factors Affecting the Investment Decision in Mutual Funds. International Journal of Research in Arts and Science, 3(2).

Kannadhasan, M. 2015. Retail investors' financial risk tolerance and their risk-taking behaviour: The role of demographics as differentiating and classifying factors. IIMB Management Review, 27(3), 175-184.

Kaveri, M. \& Bindu, B. 2017. Impact of Investors' Perception and Attitude towards Investment Decision in Mutual Funds at Velachery, Chennai. International Journal of Research in Arts and Science, 3(2), 4-9.

Kennedy, B.P. 2013. The Theory of Planned Behavior and Financial Literacy: A Predictive Model for Credit Card Debt? Marshall University, $480 \mathrm{p}$.

Khorassani, J. 2000. An empirical study of depositor sensitivity to bank risk. Journal of Economics and Finance, 24(1), 15-27.

Koropp, C., Kellermanns, F.W., Grichnik, D. \& Stanley, L. 2014. Financial decision making in family firms: An adaptation of the theory of planned behavior. Family Business Review, 27(4), 307-327.

Kourtidis, D., Šević, Ž. \& Chatzoglou, P. 2011. Investors' trading activity: A behavioural perspective and empirical results. The Journal of Socio-Economics, 40(5), 548-557.

Kunt, A.D. \& Huizinga, H. 1999. Market discipline and financial safety net design (November 1999 ed. Vol. 2311): World Bank Publication.

Kunt, A.D. \& Huizinga, H. 2004. Market discipline and deposit insurance. Journal of monetary economics, 51(2), 375-399.

Laeven, L. \& Valencia, F. 2012. Systemic banking crises database: An update. Retrieved from https://papers.ssrn.com/sol3/papers.cfm?abstract_id=2096234

Lane, T.D. 1993. Market discipline. Staff Papers, 40(1), 53-88.

Levy-Yeyati, E., Peria, M.S.M. \& Schmukler, S. 2004. Market discipline in emerging economies: Beyond bank fundamentals Market Discipline Across Countries and Industries. Cambridge, Massachusetts, MIT Press.

Levy-Yeyati, E., Martinez Peria, M.S. \& Schmukler, S.L. 2010. Depositor behavior under macroeconomic risk: Evidence from bank runs in emerging economies. Journal of Money, Credit and Banking, 42(4), 585-614.

Lindquist, K. 2003. Banks' Capital Buffer: How Important is Risk. Journal of International Money and Finance, 23, 493-513.

Magendans, J., Gutteling, J.M. \& Zebel, S. 2017. Psychological determinants of financial buffer saving the influence of financial risk tolerance and regulatory focus. Journal of Risk Research, 20(8), 1076-1093.

Mahastanti, L.A. \& Hariady, E. 2014. Determining the factors which affect the stock investment decisions of potential female investors in Indonesia. International Journal of Process Management and Benchmarking, 4(2), 186-197.

Martinez Peria, M.S. \& Schmukler, S.L. 2001. Do depositors punish banks for bad behavior? Market discipline, deposit insurance, and banking crises. The journal of finance, 56(3), 1029-1051. 
Merton, R.C. 1977. An analytic derivation of the cost of deposit insurance and loan guarantees an application of modern option pricing theory. Journal of Banking \& Finance, 1(1), 3-11.

Milhaupt, C.J. 1999. Japan's experience with deposit insurance and failing banks: Implications for financial regulatory design. Wash. ULQ, 77(2), 399-431.

Min, D. 2015. Understanding the failures of market discipline. Washington University Law Review, 92(6), 1421-1500.

Nier, E. \& Baumann, U. 2006. Market discipline, disclosure and moral hazard in banking. Journal of Financial Intermediation, 15(3), 332-361.

Ozmete, E. \& Hira, T. 2011. Conceptual analysis of behavioral theories/models: Application to financial behavior. European Journal of Social Sciences, 18(3), 386-404.

Rutherford, L. \& DeVaney, S.A. 2009. Utilizing the theory of planned behavior to understand convenience use of credit cards. Journal of Financial Counseling and Planning, 20(2), 48-63.

Schmidt, N. 2010. What drives investments into mutual funds? Applying the theory of planned behaviour to individuals' willingness and intention to purchase mutual funds. Paper presented at the Retail Investment Conference.

Shahrabani, S. 2012. The effect of financial literacy and emotions on intent to control personal budget: A study among Israeli college students. International Journal of Economics and Finance, 4(9), 156-163.

Sironi, A. 2003. Testing for market discipline in the European banking industry: evidence from subordinated debt issues. Journal of Money Credit and Banking, 35(3), 443.

Sivaramakrishnan, S., Srivastava, M. \& Rastogi, A. 2017. Attitudinal factors, financial literacy, and stock market participation. International Journal of Bank Marketing, 35(5), 818-841.

Soma, A.M., Primiana, I., Wiryono, S.K. \& Febrian, E. 2016. Determinant Analysis of Financial Literacy Affecting Market Discipline Performance. International Journal of Economics, Commerce and Management, IV(12), 76-97.

Sondakh, J.J. 2017. Behavioral Intention to Use E-Tax Service System: An Application of Technology Acceptance Model. European Research Studies Journal, 20(2A), 48-64.

Sondary, M.C. \& Sudarsono, R. 2015. Using Theory of Planned Behavior in Predicting Intention to Invest: Case of Indonesia. International Academic Research Journal of Business and Technology, 1(2), 137-141.

Stephanou, C. 2010. Rethinking market discipline in banking: lessons from the financial crisis: The World Bank.

Widdowson, D. \& Hailwood, K. 2007. Financial literacy and its role in promoting a sound financial system. Reserve Bank of New Zealand Bulletin, 70(2), 37-47.

Widyastuti, U., Suhud, U. \& Sumiati, A. 2016. The Impact of Financial Literacy on Student Teachers' Saving Intention and Saving Behaviour. Mediterranean Journal of Social Sciences, 7(6), 41-48.

Xiao, J.J., Tang, C., Serido, J. \& Shim, S. 2011. Antecedents and consequences of risky credit behavior among college students: Application and extension of the theory of planned behavior. Journal of Public Policy \& Marketing, 30(2), 239-245.

Xiao, J.J. \& Wu, J. 2006. Applying the theory of planned behavior to retain credit counseling clients. Retrieved from https://papers.ssrn.com/sol3/papers.cfm?abstract_id=939437 